\title{
Herkkyys ja yksilölliset olemisen kehykset
}

Anne Airaksinen ja Janna Satri

\section{TIIVISTELMÄ}

- Erityisherkkyyden käsite on tullut viime vuosina tutuksi popularisoidusta tietokirjallisuudesta. Tieteellisestikin käsite on kiinnostava mutta näyttäytyy monimuotoisesti useiden eri käsitteiden alla, joita yhdistävät yksilöiden väliset herkkyyserot ja herkkyys ympäristölle. Tässä artikkelissa käsittelemme herkkyyden ilmiötä ja tuomme esille siihen liittyvää tieteellistä käsitteistöä sekä kotimaista ja kansainvälistä tutkimusta. Vuorovaikutuksellisena, yhteisöllisenä ja yhteiskunnallisena ulottuvuutena hahmottelemme esiin niin kutsuttua olemisen kehystä, olemisen ja toiminnan ympäristöä, jossa yksilö toimii, kasvaa ja kehittyy. Yksilölliset olemisen kehykset avaavat näkymiä kohti herkkyydeltään erilaisten ihmisten toimijuutta ja toiminnan mahdollisuuksia. Tämä on uusi avaus, joka kohdentuu yksilön ja ympäristön välisen vuorovaikutussuhteen sekä sen laadun tarkastelemiseen yksilölliset herkkyyserot huomioiden. Herkkyyden teoreettinen tarkastelu avaa mahdollisuuksia jatkotutkimuksille. Sosiaali- ja yhteiskuntatieteellistä tutkimusta tarvitaan laajentamaan herkkyyden ja herkkyyserojen tutkimuskenttää.

Asiasanat: herkkyys, herkkyys ympäristölle, erityisherkkyys, toimijuus, toimintamahdollisuudet 


\section{ABSTRACT \\ SENSITIVITY AND THE INDIVIDUAL FRAMEWORK OF BEING}

- In recent years, the concept of being a highly sensitive person has come to be known through popular science. Even in scholarship, it is an interesting concept, but it appears in various forms under several different concepts which are all united by inter-individual differences in sensitivity and sensitivity to environments. This article discusses the phenomenon of sensitivity, highlighting its scholarly terminology as well as Finnish and international research on the subject. It outlines what we call a framework of being, covering an interactive, communal and societal dimension. This framework refers to an environment involving existence and activity, where an individual functions, grows and develops. Individual frameworks of being provide an overview of different people's agency and capabilities in terms of their sensitivity. This is a new way to examine the subject, targeted towards the interactive relationship between an individual and an environment as well as the analysis of its nature, taking individual differences in sensitivity into account. The theoretical analysis of sensitivity opens up opportunities for further research. Social science research is required for expanding the field of study involving sensitivity and differences in sensitivity.

Keywords: sensitivity, environmental sensitivity, highly sensitive person (HSP), agency, capabilities

\section{Johdanto}

$\mathrm{N}$ iin ihmisillä kuin eläimilläkin on yksilöllisiä eroja herkkyydessä ja reaktiivisuudessa (Belsky \& Pluess 2009; Ellis, Boyce, Belsky, Bakermans-Kranenburg \& van IJzendoorn 2011; Greven ym. 2019). Yksilölliset reagointikykyyn liittyvät eroavaisuudet ovat liitoksissa kykyyn ja herkkyyteen vastata ympäristön ärsykkeisiin (Wolf, van Doorn \& Weissing 2008, 15825). Tässä artikkelissa tarkastelemme ihmisten eriasteista herkkyyttä ympäristölleen, pohjautuen aiempaan tieteelliseen tutkimukseen.

Artikkelimme alkaa herkkyyden ilmiön ja siihen liittyvien käsitteiden kuvailulla. Suomessa on viime vuosina tullut melko laajasti tunnetuksi Elaine N. Aronin tietokirjoissaan käyttämä highly sensitive person (HSP) -käsite. Se on suomennettu erityisherkkyydeksi, ja sitä voidaan kuvata erityisen herkän ihmisen elämässä monimuotoisesti vaikuttavana aistien ja tunteiden herkkyytenä. (Ks. esim. Aron 2013.) Tieteellisissä teksteissä herkkyys esiintyy useiden eri käsitteiden alla. Tässä artikkelissa keskitym- 
me suomalaisen uranuurtajan Sylvi-Sanni Mannisen (ent. Honkavaara) tutkimuslöytöihin sekä uudempiin kansainvälisiin tutkimuksiin.

Herkkyys ympäristölle on perustaltaan neurobiologista (Ellis ym. 2011), ja sitä on kuvattu esimerkiksi stressireaktiivisuutena (Boyce \& Ellis 2005). Tuoreen kotimaisen tutkimuksen mukaan yksilöiden välisiin herkkyyseroihin vaikuttavat neurobiologiset tekijät ovat havaittavissa jo vastasyntyneillä (Nolvi ym. 2020). Herkkyyttä on selitetty liittäen se herkkien yksilöiden taipumukseen havaita hienovaraisia eroavaisuuksia ja prosessoida niitä (Aron \& Aron 1997, 348-350; de Villiers, Lionetti \& Pluess 2018, 549-550). Synnynnäisenä neurobiologisena ominaisuutena herkkyys voidaan määrittää osaksi temperamenttia eli persoonallisuuden biologista ydintä. Ihmisillä on aina monia eri temperamenttipiirteitä, joista muodostuu yksilöllinen yhdistelmä sen mukaan, millaiset piirteet yksilön temperamentissa korostuvat (temperamentista ks. esim. Keltikangas-Järvinen 2009; 2016).

Aronin tietokirjoissaan esittämän tiedon mukaan erityisherkkiä ihmisiä on noin 15-20 prosenttia väestöstä (Aron 2013, 23). Pluessin ym. (2018) lapsille ja nuorille tekemässä tutkimuksessa ja Lionettin ym. (2018) aikuisille tekemässä tutkimuksessa jopa 30 prosenttia koehenkilöistä voitiin tulkita herkimpien ryhmään kuuluviksi, 40 prosenttia keskivertoherkiksi ja 30 prosenttia matalasti herkiksi, mutta prosenttiosuudet riippuvat myös tutkimusaineistojen tulkinnasta.

Tässä artikkelissa tarkastelemme ensin herkkyyden tutkimuskenttää ja siellä esitettyjä keskeisimpiä käsitteitä. Tämän jälkeen kiinnitämme katseen siihen olemisen ja toiminnan ympäristöön, jossa yksilö kasvaa, kehittyy, toimii ja ilmaisee itseään. Käytämme tästä nimitystä olemisen kehys. Olemisen kehystä tarvitaan havainnollistamaan sitä, miten ympäristössä vallitsevat arvot, niitä seuraavat asenteet ja ihanteet, ympäröivä kulttuuri, sosiaaliset suhteet sekä yhteiskunnalliset rakenteet vaikuttavat yksilöiden kokemusmaailmaan. Ympäristön vaikutukset nähdään kokonaisvaltaisesti merkityksellisinä ihmisen hyvinvoinnille, kasvulle ja kehitykselle (ks. Bronfenbrenner 1977; Pluess 2015). Yksilöllisesti muovautuva olemisen kehys yhdessä yksilön ominaisuuksien kanssa avaa näkymiä edelleen yksilön toimijuuden muodostumiseen, ilmentymiseen ja rakentumiseen sekä toimintamahdollisuuksien merkitykseen. Artikkelissa tarkasteltava yksilöllinen herkkyys on yksi niistä ominaisuuksista, jotka vaikuttavat olemisen kehyksen kautta konkretisoituvaan toimintaan, kasvuun, kehitykseen ja hyvään elämään. 
Aiempi herkkyyden tutkimus on ollut näkökulmaltaan pääosin psykologista. Sosiaali- ja yhteiskuntatieteellistä tutkimusta herkkyydestä tarvitaan, jotta ilmiöön saataisiin uusia näkökulmia. Tämä uusi avaus kohdentuu yksilön ja ympäristön välisen vuorovaikutussuhteen ja sen laadun tarkastelemiseen yksilölliset herkkyyserot huomioiden. Lisäksi keskeisenä tavoitteenamme on tuoda herkkyyttä kuvaava käsitteistö mukaan suomenkieliseen tieteelliseen keskusteluun.

\section{Herkkyys tutkimuksissa}

Tutkimuksissa esiintyy useita erilaisia käsitteitä, jotka kuvaavat samaa herkkyyden ilmiötä eri näkökulmista. Aron ja Aron (1997) ovat aloittaneet tutkimuksillaan tieteellisen keskustelun sensory-processing sensitivity -käsitteen alla. Uudemmissa tutkimuksissa keskeiseksi käsitteeksi on muodostunut environmental sensitivity (esim. Pluess 2015; Pluess ym. 2018), joka kuvaa laajasti ihmisten erilaista herkkyyttä ympäristön sekä myönteisille että kielteisille vaikutuksille. Herkkyys ympäristölle voidaan nähdä yläkäsitteenä: se kokoaa yhteen painotuksiltaan erilaisia teoreettisia viitekehyksiä, jotka tarkastelevat ja selittävät ihmisten välisiä herkkyyseroja. Ensimmäisiä herkkyyden tutkijoita oli Sylvia Honkavaara (esim. 1958a; 1958b; 1958c), joka tutki ihmisten eriasteista havaintomaailman herkkyyttä. Avaamme herkkyyden tutkimuskenttää aloittaen varhaisesta suomalaisesta tutkimustyöstä, ja sen jälkeen siirrymme tarkastelemaan uudempaa kansainvälistä tutkimusta.

\section{Suomalaisen uranuurtajan tutkimustyö}

Sylvi-Sanni Manninen (ent. Sylvia Honkavaara) tutki yliherkiksi väri-ihmisiksi nimeämiään ihmisiä jo 1950-luvulla mutta esitteli tutkimuksensa suomen kielellä vasta paljon myöhemmin (Manninen 1999). Manninen (1999, 12) kuvailee löytäneensä elämäntyössään uuden ihmistyypin, erityisen herkän ihmislajin, "joka on liian usein syyttä musertunut lajitoveriensa kyynärpäihin, peukalon alle tai jalkoihin”. Hän vertaa herkkää ihmistä hienorakenteiseen koneeseen, joka särkyy helposti (Manninen 1999, 170). Manninen kehitti havaintoon perustuvan persoonallisuustestin herkkyyden ja sen asteen tunnistamiseksi (ks. Honkavaara 1958a; Manninen 1999, 131-136). Herkistä ihmisistä hän käytti nimitystä "väri-ihmiset" johtuen siitä, että hänen mukaansa herkkyydestä kertoo ihmisen suhtautuminen väreihin. Vähemmän herkkiä hän kutsui "muotoihmisiksi”. (Manninen 1999, 13.) Englanninkielisissä teksteissään hän käytti 
käsitteitä color-reactor ja form-reactor (esim. Honkavaara 1958b; 1958c) sekä näitä vastaavaa vastinparia color responsive ja form responsive (Honkavaara 1964).

Varsinkin tieteellisissä artikkeleissa (esim. Honkavaara 1958c; 1964) herkkyys tai sensitiivisyys väriin reagoivien henkilöiden ominaisuutena tulee eksplisiittisesti esille vain paikoitellen silloin, kun Honkavaara kuvaa tutkimiensa ihmistyyppien ominaislaatua ja keskinäisiä eroja. Väri-ihmisille on tyypillistä herkkä havaintokyky (Honkavaara 1958c, 46), ja he ovat reaktiivisempia, intuitiivisempia ja luovempia kuin muotoihmiset, jotka puolestaan ovat realistisempia ja vaikuttavat sosiaalisesti itsevarmemmilta kuin väri-ihmiset (Honkavaara 1958b, 26; 1958c, 39). Väri-ihmisille on ominaista leikkisyys silloin, kun ympäristö on heille otollinen (Honkavaara 1964,175$)$.

Perustavanlaatuisena erona Honkavaara (1964) esittää, että väri- ja muotoihmisten erilaiset piirteet ovat seurausta heidän erilaisista psyykkisistä rajoistaan, jotka suojaavat yksilöä ympäristön ärsykkeiltä. Muotoihmisillä nämä rajat ovat paksut, väri-ihmisillä puolestaan ohuet (kuvio 1). Tästä seuraa, että väri-ihminen on olemukseltaan vaihtelevampi, muotoihminen puolestaan jäykempi ja helpommin muuttumattomana pysyvä. (Honkavaara 1964, 174-175.) Honkavaaran tutkimustyössä tulee esille ympäristön vaikutusten painottaminen nimenomaan herkkien yksilöiden näkökulmasta. Hän vertaa ihmisiä kasveihin, jotka tarvitsevat tietynlaista maaperää kukoistaakseen (Honkavaara 1958c, 45, 47).
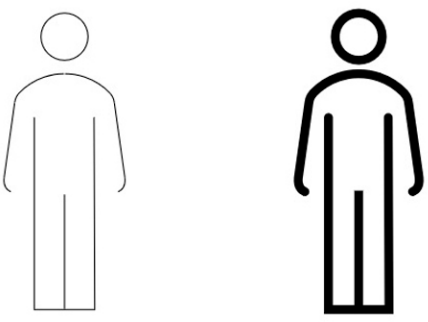

KUVIO 1. Herkkyydeltään erilaisten ihmisten psyykkiset rajat, kaksi ääripäätä (mukaillen Honkavaara 1964, 175 ja Manninen 1999, 17)

Erityisen herkän ihmisen kannalta edellä kuvatuilla eroilla saattaa olla suuri merkitys, koska ne luovat sitä tapaa, jolla ihminen kokee todellisuuden, ja samalla ne voivat vaikuttaa siihen, millaiseksi hänen elämän- 
sä yhteiskunnassa muotoutuu. Herkät väri-ihmiset uudistavat kulttuuria, muotoihmiset puolestaan ylläpitävät olemassa olevia rakenteita (Honkavaara 1964, 176; Manninen 1999, 17). Mannisen mukaan uuden todellisuuden esiinmurtautuminen esimerkiksi taiteessa on herkän väri-ihmisen aikaansaannosta ja nostattaa usein vastareaktioita, mikä voi olla luovalle yksilölle raskasta (Manninen 1999, 57, 171-172).

Mannisen uraauurtava tutkimustyö viitoittaa tietä uudelle kotimaiselle herkkyystutkimukselle, joka on toistaiseksi ollut suhteellisen vähäistä. Seuraavaksi siirrymme tarkastelemaan uudempia kansainvälisiä herkkyystutkimuksia.

\section{Yhdysvalloista alkanut herkkyystutkimus}

Kansainvälisen herkkyystutkimuksen keskeisimpiä uranuurtajia ovat Elaine ja Arthur Aron. He käyttävät herkkyyttä tarkastelevissa kirjoituksissaan kahta eri käsitettä. Suurelle yleisölle suunnatuissa tietokirjoissaan Elaine Aron (esim. 2013) käyttää käsitettä highly sensitive person (HSP). Tutkimusartikkeleissaan Elaine ja Arthur Aron (esim. 1997) käyttävät käsitettä sensory-processing sensitivity (SPS), joka voidaan suomentaa aistitiedon käsittelyn herkkyydeksi (Aron 2013, 11). Ominaisuutena se ei ole lähtökohtaisesti aistiyliherkkyyttä (vrt. Ollila \& Kujala 2020, 92) vaan laajemmin vaikuttava ominaisuus. Aronin ja Aronin (1997) mukaan siinä on keskeistä taipumus havaita hienovaraisia eroavaisuuksia ja prosessoida niitä. Aistitiedon käsittelyn herkkyys saattaa näkyä ulospäin vetäytymistaipumuksena (behavioral inhibition system, BIS) mutta on pikemminkin reflektiivisyyttä kuin pelokkuutta. (Aron \& Aron 1997, 348-350.)

Aronin ja Aronin (1997) tutkimuksessa syvähaastateltiin ensin itsensä erityisen herkiksi tunnistavia aikuisia käsitteen määrittelyn luomiseksi, minkä jälkeen luotiin mittari määrällisin menetelmin (Highly Sensitive Person Scale, HSPS). Tutkimuksessa käytetty 27-kohtainen, pisteytetty HSPS-testi eroaa itsearviointitestistä, johon annetaan kyllä/ei-vastauksia (Aron \& Aron 1997; Aron 2013; testien tutkimuskäytöstä ks. Aron \& Aron 2018). Kehitysvaiheessa lopullinen testi on lyhennetty 60 kysymyksestä (Aron, Aron \& Jagiellowicz 2012, 272-273). Lapsille on kehitetty oma kyselytesti (Highly Sensitive Child Scale, HSCS) herkkyyserojen mittaamiseksi (Pluess ym. 2018). Aivokuvantamistutkimuksissa on todettu HSPS-testin perusteella matalasti ja korkeasti herkiksi määritettyjen henkilöiden välillä eroavaisuuksia aivoalueiden aktivoitumisessa (Acevedo ym. 2014; Jagiellowicz ym. 2011). 
Aronien tutkima aistitiedon käsittelyn herkkyys on eri ominaisuus kuin sosiaalinen introversio tai emotionaalisuus, mutta erityisen herkkien aikuisten voimakkaalla introversiolla ja kielteisellä emotionaalisuudella näyttää olevan yhteyttä ongelmalliseen lapsuuteen (Aron \& Aron 1997, 362-364; Aron, Aron \& Davies 2005). Kasvu- ja toimintaympäristöillä näyttääkin olevan keskimääräistä suurempi vaikutus erityisen herkkiin yksilöihin. Lasten temperamenttia käsittelevissä tutkimuksissa on tutkittu monia eri temperamenttipiirteitä. Esimerkiksi Slagtin, Dubasin, Dekovićin ja van Akenin (2016) vanhemmuuden laadun ja lapsen temperamentin vuorovaikutusta tarkastellut meta-analyysi nostaa esille niin kutsutun vaikean ja helpon temperamentin, joista ensin mainittua luonnehtii kielteinen emotionaalisuus. On huomattava, että herkkyys on eri piirre kuin kielteinen emotionaalisuus tai sen pohjalta muotoutuva neuroottisuus persoonallisuuspiirteenä (neuroottisuudesta ks. Metsäpelto \& Rantanen 2009, 76-77).

Elaine ja Arthur Aron kehittivät HSPS-testin alun perin arvioimaan herkkyyttä yksiulotteisena ominaisuutena (Aron \& Aron 1997; Lionetti ym. 2018). Sittemmin herkkyyden tarkasteluun on avattu lisää ulottuvuuksia. Smolewskan, McCaben ja Woodyn (2006) tutkimuksen pohjalta herkkyyttä on alettu tutkimuksissa eritellä kolmeen erilaiseen ulottuvuuteen (kuvio 2): esteettiseen herkkyyteen (aesthetic sensitivity, AES), matalaan ärsykekynnykseen (low sensory threshold, LST) ja virittymistaipumukseen (ease of excitation, EOE).

Herkkyyttä ja sen ulottuvuuksia tutkittaessa on selvitetty niiden yhteyttä viiteen suureen persoonallisuuspiirteeseen, jotka ovat neuroottisuus eli tunne-elämän epätasapainoisuus, ekstraversio eli ulospäin suuntautuneisuus, avoimuus uusille kokemuksille, sovinnollisuus ja tunnollisuus (persoonallisuuspiirteistä ks. Metsäpelto \& Rantanen 2009) sekä esimerkiksi negatiiviseen ja positiiviseen affektiivisuuteen eli taipumukseen kokea kielteisiä ja myönteisiä tunnereaktioita. Herkkyys ympäristölle on osittain päällekkäistä muiden piirteiden kanssa (Assary, Zavos, Krapohl, Keers \& Pluess 2021; Lionetti ym. 2019). Herkkyyden periytyvyyttä selvittäneen laajan kaksostutkimuksen mukaan noin 20 prosenttia herkkyyden vaihtelusta ei selity muilla piirteillä (Assary ym. 2021).

Lionetti ym. (2019) analysoivat katsausartikkelissaan yhteensä 24 tutkimusta, joissa on käytetty HSPS- tai HSCS-testiä ja tutkittu herkkyyden ja sen osa-alueiden sekä muiden piirteiden yhteyttä toisiinsa (ks. myös Assary ym. 2021). Tässä meta-analyysissa havaittiin, että viiden suuren 
persoonallisuuspiirteen osalta sekä lasten että aikuisten herkkyys oli yhteydessä neuroottisuuteen, ja aikuisten herkkyys korreloi lisäksi avoimuuteen uusille kokemuksille. Lisäksi lasten herkkyydellä oli yhteyttä sekä negatiiviseen että positiiviseen affektiivisuuteen mutta aikuisilla vain negatiiviseen affektiivisuuteen. (Lionetti ym. 2019.) Lasten ja aikuisten erilaisiin tuloksiin saattaa vaikuttaa se, että lasten testi on kehitetty erilaisista lähtökohdista: siitä on esimerkiksi poistettu aikuisten testissä ilmenevää kielteisten tunteiden painottumista (Lionetti ym. 2019, 150). Aikuisten testistä on aikanaan jätetty pois myönteisten tunteiden voimakkuuteen liittyvät kysymykset, vaikka nekin erottuivat Aronin ja Aronin (1997) haastatteluaineistosta (Aron ym. 2012, 273).

Lionettin ym. (2019) meta-analyysissä erottunut avoimuus uusille kokemuksille on piirre, jota luonnehtii sosiaalisen avoimuuden sijasta esimerkiksi rikas sisäinen elämä ja älyllinen uteliaisuus. Avoimuus uusille kokemuksille voimistaa myönteisten ja kielteisten tunteiden kokemista mutta ei neuroottisuudesta poiketen varsinaisesti altista kielteisille tunnereaktioille. (Metsäpelto \& Rantanen 2009, 77-78.)

Herkkyyden osa-alueita on tutkittu myös suhteessa yksilöllisiin voimavara- ja haavoittuvuustekijöihin hyödyntäen työn vaatimusten ja voimavarojen mallia (Vander Elst ym. 2019). Olemassa olevia psykologisia mittareita olisikin mahdollista soveltaa tutkimuksissa laajasti esimerkiksi työkontekstiin.

Seuraavaksi siirrymme tarkastelemaan evoluutiobiologiasta ja lasten kehityspsykologiasta alkunsa saaneita teorioita. Ne tarjoavat selitysmalleja ympäristön vaikutuksiin ja siihen, miten eri voimakkuudella herkkyydeltään erilaiset yksilöt saattavat reagoida ympäristönsä kielteisiin vaikutuksiin ja toisaalta sosiaalisesta ympäristöstään saamaansa tukeen.

\section{Herkkyys ympäristölle uusien näkökulmien avaajana}

Viime vuosina julkaistuissa tutkimuksissa esiintyvä käsite environmental sensitivity (Pluess ym. 2018) linkittyy Aronien tutkimaan aistitiedon käsittelyn herkkyyteen. Pluessin ym. (2018, 52-53) mukaan on olemassa kolme keskeistä "ympäristöherkkyyden" mallia (ks. kuvio 2.): Aronin ja Aronin (1997) tutkima aistitiedon käsittelyn herkkyys (sensory-processing sensitivity), Jay Belskyn ja Michael Pluessin (Belsky 1997; Belsky \& Pluess 2009) eriävän alttiuden teoria (differential susceptibility theory), sekä Thomas Boycen ja Bruce Ellisin (2005) biologinen kontekstiherkkyys (biological sensitivity to context). 


\section{PLUESS:}

Herkkyys ympäristölle (environmental sensitivity), kolme mallia

BELSKY \& PLUESS:

Eriävä alttius (differential susceptibility)
ARON \& ARON:

Aistitiedon käsittelyn herkkyys (sensory processing sensitivity)
BOYCE \& ELLIS:

Biologinen kontekstiherkkyys (biological sensitivity to context)

\begin{tabular}{|c|c|}
\hline $\begin{array}{c}\text { Kielteisen } \\
\text { altistuksen } \\
\text { pitkäaikais- } \\
\text { vaikutukset } \\
\text { toiminta- } \\
\text { kykyyn; } \\
\text { haavoittu- } \\
\text { vuusstressi } \\
\text { (diathesis } \\
\text { stress) }\end{array}$ & $\begin{array}{c}\text { Ympäristön } \\
\text { tuki ja } \\
\text { toiminta- } \\
\text { kykyä } \\
\text { rakentavat } \\
\text { pitkäaikais- } \\
\text { vaikutukset; } \\
\text { hyöty- } \\
\text { herkkyys } \\
\text { (vantage } \\
\text { sensitivity) }\end{array}$ \\
\hline
\end{tabular}

\section{SMOLEWSKA, MCCABE \& WOODY: \\ Aistitiedon käsittelyn herkkyyden ulottuvuudet}

- Esteettinen herkkyys (aesthetic sensitivity)

- Matala ärsykekynnys (low sensory threshold)

- Virittymistaipumus (ease of excitation)

KUVIO 2. Käsitekartta (mukaillen Greven ym. 2019, 290)

Ellis ym. (2011) painottavat, että herkkyys ympäristölle ja siinä ilmenevät erot ovat perustaltaan neurobiologisia (ks. myös Greven ym. 2019; Nolvi ym. 2020). Belskyn ja Pluessin $(2009,886)$ mukaan eriävän alttiuden teoria painottaa enemmän yksilöiden välisiä luontaisia ominaisuuksia (nature), kun biologinen kontekstiherkkyys puolestaan korostaa enemmän ympäristön tuottamaa vaikutusta yksilön ominaisuuksien muotoutumisessa (nurture). Eriävä alttius ja biologinen kontekstiherkkyys ovat molemmat evoluutiobiologiaan pohjautuvia teorioita, ja niissä on erilaisista selitysmalleistaan huolimatta paljon yhtäläisyyksiä (Ellis ym. 2011). Lajin säilymisen kannalta on merkityksellistä, että on olemassa herkkyydeltään erilaisia yksilöitä (Belsky \& Pluess 2009, 887; ks. myös Aron ym. 2012, 264; Ellis ym. 2011, 9-10; Wolf ym. 2008).

Eriävän alttiuden viitekehyksen mukaan erityisen altis yksilö voi olosuhteista riippuen saada joko erityistä haittaa tai hyötyä kehitykselleen riippuen geeni-ympäristö- tai temperamentti-vanhemmuus-suhteen laadusta. Kyseinen tilanne onkin erotettava niin kutsutusta kaksoisriskistä (dual risk), jossa yksilö on haavoittuvaisempi haitallisille ympäristöteki- 
jöille ilman, että hänelle otollisissakaan olosuhteissa koituisi hyötyä geenivariantistaan tai temperamentistaan. (Belsky, Bakermans-Kranenburg \& van IJzendoorn 2007, 301-302.) Perinteisiin kaksoisriskiä tai haavoittuvuusstressiä (diathesis stress) painottaviin selitysmalleihin tukeutuminen voi johtaa siihen, että ei havaita yksilön ominaisuuksien voivan tuottaa kielteisten vaikutusten lisäksi yhtä lailla myönteisiäkin vaikutuksia (Belsky \& Pluess 2009, 887-888; Ellis ym. 2011).

Vantage sensitivity (Pluess \& Belsky 2013), joka voitaisiin suomentaa hyötyherkkyydeksi, on käsitteenä kehitetty tavoittamaan diathesis stress -ilmiön vastakohta. Hyötyherkkyys ei ole samaa kuin resilienssi, vaan vahvan resilienssin omaava yksilö saattaa olla vastustuskykyinen yhtä lailla ympäristönsä myönteisillekin vaikutuksille. Hyötyherkkyydessä on kyse siitä, että tietyt luontaisesti herkät yksilöt voivat saada erityistä hyötyä ympäristönsä tarjoamista myönteisistä kokemuksista. Toisin kuin eriävän alttiuden teoriassa hyötyherkkyyttä tutkittaessa ei edellytetä sen osoittamista, että herkät yksilöt kokisivat sekä myönteisiä että kielteisiä vaikutuksia altistuttuaan vastaaville ympäristötekijöille. (Pluess \& Belsky 2013, 903-905.)

Vantage sensitivity -ilmiölle on saatu tukea kouluikäisille tehdyistä interventiotutkimuksista, joissa on ennaltaehkäisty masennusta (Pluess \& Boniwell 2015) sekä koulukiusaamista ja sen vaikutuksia (Nocentini, Menesini \& Pluess 2018). Näissä tutkimuksissa osallistujien herkkyyttä arvioitiin käyttämällä HSCS-testiä eli lapsille ja nuorille suunnattua herkkyystestiä. Tuloksissa näkyi interventioiden myönteinen vaikutus nimenomaan herkimpien ryhmään ja toisaalta vähäinen tai olematon vaikutus matalasti herkkien ryhmässä. Iimura ja Kibe (2020) tarkastelevat teoreettisten mallien toimivuutta lukioon siirtymistä käsittelevässä tutkimuksessaan ja toteavat erityisen herkkien oppilaiden hyvinvoinnin parantuneen eniten lukioon siirryttäessä, joskin tutkimuksen otos saattaa olla valikoitunut.

De Villiersin, Lionettin ja Pluessin $(2018,551)$ mukaan tarvitaan lisää tutkimuksia, jotta vantage sensitivity -ilmiö opitaan tuntemaan yksityiskohtaisemmin. Saadut tulokset ovat kuitenkin lupaavia, koska niiden kautta avautuu näkymiä muun muassa psykoterapeuttisten ja psykiatristen hoitointerventioiden yksilölliseen, ennakoivaan kohdentamiseen (de Villiers ym. 2018, 550-551). Myös Honkavaara (1958c; ks. myös Manninen 1999) on tuonut esille yksilöllisten ratkaisujen tarpeellisuuden sekä mahdollisuuden tunnistaa ihmisen yksilölliset ominaisuudet esimerkiksi herkkyyttä mittaavan testin avulla. 
Edellä esitellyt teoreettiset näkökulmat ja empiiriset tutkimukset osoittavat, että erityisen herkkien tai alttiiden yksilöiden luontaiset ominaisuudet saattavat olla ympäristöstä riippuen joko haitallisia tai hyödyllisiä, kun taas vähemmän herkkiä yksilöitä luonnehtii suurempi resistenssi ympäristön vaikutuksille. Nämä teoreettiset näkökulmat ja tutkimustulokset avaavat mahdollisuuksia lisätutkimuksille. Niiden pohjalta voidaan esittää myös käytännön kysymyksiä siitä, miten yksilöllisiin eroihin ihmisten erilaisessa herkkyydessä tulisi suhtautua ja minkä tyyppisille ihmisille erilaiset yhteiskunnalliset ympäristöt sopivat parhaiten.

\section{Yksilön herkkyys ja ympäristö}

Yksi sosiaalipedagogisen ajattelun kulmakivistä on pyrkimys ymmärtää sitä todellisuutta, jossa ihmiset elävät ja kasvavat. Ymmärryksen laajentamiseksi on tärkeää rakentaa siltoja eri tieteenalojen välisen keskustelun kautta. (Nivala \& Ryynänen 2019, 331.) Edellä olemme kuvanneet herkkyyttä ympäristölle aiemman psykologisen tutkimuskirjallisuuden pohjalta, ja sen rinnalle liitämme sosiaalipedagogisen näkökulman. Tämä tuo herkkyyden tarkasteluun jotakin uutta: ihmisen käsitys omasta herkkyydestään muovautuu sosiaalisissa suhteissa, vuorovaikutuksessa ympäristön kanssa. Yksilön ja ympäristön välisen vuorovaikutussuhteen tarkastelemiseksi tulee yksilöllisten ominaisuuksien lisäksi olla tietoinen myös ympäristön ominaisuuksista sekä tunnistaa niitä toimintakenttiä ja -muotoja, joissa yksilön ja ympäristön välistä vuorovaikutusta tapahtuu. Seuraavaksi tarkastelemme yksilön ja ympäristön välistä vuorovaikutusta herkän yksilön toimijuuden ja toimintamahdollisuuksien näkökulmista.

\section{Ympäristö toiminnan ja olemisen kehyksenä}

Ympäristön vaikutukset ihmisen selviytymiseen, kasvuun, kehitykseen ja menestymiseen ovat kiistattomat: esimerkiksi kasvava ja kehittyvä lapsi on täysin riippuvainen saamastaan tuesta ja huolenpidosta (Pluess 2015, 138). Myös luontaisen temperamentin ja ympäristön välisellä suhteella on vaikutuksensa yksilön kehitykseen (Jagiellowicz, Aron \& Aron 2016, 187). Ympäristöllä tarkoitamme tässä artikkelissa kaikkea yksilöä ympäröivää, jonka kanssa yksilö on vuorovaikutuksessa. Tähän ymmärrämme laveasti kuuluvaksi erilaiset vuorovaikutuksellisuuteen ja ihmissuhteisiin liittyvät ulottuvuudet, jotka voivat olla yhteisöllisiä tai yhteiskunnallisia. Näihin ulottuvuuksiin on sidoksissa myös kulttuurisia ja rakenteellisia tekijöitä. Lisäksi yksilöä ympäröi fyysisesti sekä luontoympäristö että rakennettu ympäristö. 
Ympäristö muodostaa ihmisen toiminnalle kehykset, joissa hän kasvaa ja kehittyy yksilönä sekä muodostaa käsitystä itsestään. Yksilöä ympäröi myös "ajan henki", joka sisältää kaiken läpäisevästi aikakauden arvot ja arvostukset. Tähän ajan henkeen sisältyy tiedostamattomiakin vivahteita ja näkemyksiä, jotka konkretisoituvat arjessamme mutta ovat kuitenkin nimettävissä olevia. (Värri 2002, 92.) Yksilön ja ympäristön välisen vuorovaikutussuhteen tärkeyttä tukee sosiaalipedagoginen ymmärrys ihmisen yhteisöllisestä olemuksesta suhteessa ihmisen yksilöllisyyteen: ihmisyys toteutuu sosiaalisessa ympäristössä, joka toimii yksilön kasvualustana (Nivala \& Ryynänen 2019, 89, 91).

Yksilön ja ympäristön välinen vuorovaikutus konkretisoituu yksilön käyttäytymisen, kasvun ja kehityksen kautta. Yksilö voi kokea olevansa joko hyväksytty tai jollakin tavalla vääränlainen suhteessa ympäristöönsä. Keskinäinen yhteensopivuus ilmenee esimerkiksi silloin, kun yksilön toiminta on ympäristön odotusten mukaista: tällöin ympäristö tukee toivotunlaista kehitystä. Yhteensopivuus voi kuvastua tilannekohtaisesti esimerkiksi ihmisten välisessä kanssakäymisessä. (Chess \& Thomas 1991; Hipson \& Séguin 2020; Keltikangas-Järvinen 2016, 124-126.)

Tässä artikkelissa hahmottelemamme olemisen kehys on nähtävissä vuorovaikutuksellisena, ihmissuhteisiin liittyvänä, yhteisöllisenä ja yhteiskunnallisena kehyksenä, jonka kautta yksilö elää omaa kokemusmaailmaansa. Kehykseen sisältyviä ulottuvuuksia voidaan rinnastaa Bronfenbrennerin (1977) ekologisen systeemiteorian mukaisiin ympäristötasoihin, joilla jokaisella on merkityksensä yksilön kehitykselle: mikro-, meso-, ekso-, makro- ja kronosysteemiin. Esimerkiksi mikrosysteemiin liittyvät ympäristötekijät voivat kuitenkin olla hyvin yksilökohtaisia, joten näyttäisi olevan mahdotonta kuvailla yleisellä tasolla sitä, millaiseksi yksilöllinen olemisen kehys lopulta muotoutuu.

Yksilöt voivat kokea ympäristössään vallitsevat olosuhteet hyvin eri tavoin. Kokemusmaailman eroavaisuuksien lisäksi myös reagointi ympäristöön on yksilöllistä. (Sobocko \& Zelenski 2015, 44.) Ympäristön kulttuuriset, sosiaaliset ja materiaaliset ulottuvuudet ohjaavat kussakin ympäristössä tapahtuvia tekoja ja toimintaa. Konkreettisen toiminnan kautta syntyy kokemuksia, joiden pohjalta yksilö muodostaa käsitystä omasta itsestään ja kyvyistään. Erilaiset kokemukset sekä muodostuneet käsitykset omasta itsestä suuntaavat ja ohjaavat yksilön toimijuutta edelleen. (Åkerblad 2014, 44.)

Toimijuudella tarkoitetaan yksinkertaisimmillaan ihmisen halua, ky- 
kyä ja mahdollisuutta omiin valintoihin sekä valitsemansa kaltaiseen toimintaan (Nivala \& Ryynänen 2019, 95). Toimijuus itsessään muodostuu toiminnan mahdollisuuksien, resurssien ja ehtojen välisessä suhteessa. Tähän suhteeseen vaikuttavat väistämättä myös valta ja sen jakaantuminen. Toimijuuteen ovat vahvasti liitoksissa sekä toiminnan mahdollisuudet että vapaus valita näiden mahdollisuuksien joukosta. (Ronkainen 2008, 388.)

Toimijuus on kontekstisidonnaista siten, että siinä yhdistyvät yksilö-, yhteisö-, ja yhteiskunnallinen taso (Laulainen 2010, 27). Siinä, missä yksilön tekemät valinnat toimivat elämänkulun askelmina, ne myös heijastelevat näiden valintojen taustalla vaikuttavia reunaehtoja, joiden rajaamina tietyt valinnat tehdään (Vaattovaara 2015, 41-42). Erilaiset reunaehdot määrittävät toimijuutta valinnan mahdollisuuksien, käytettävien resurssien, rajoitusten ja pakkojen kautta. Yksilön on toimijuudessaan huomioitava nämä erilaiset tekijät ja lainalaisuudet useilla eri tasoilla. (Jyrkämä 2008,191 .) Niinpä yksilölliset valinnat voivat kertoa muun muassa yhteiskunnallisista olosuhteista (Vaattovaara 2015, 41). Kulttuurin vaikutuksesta yksilöön kohdistuu odotuksia ja vaatimuksia tietynlaisesta reagoimisesta ympäristöön, mikä voi vahvistaa tai heikentää yksilön toimijuutta (Keltikangas-Järvinen 2016, 106-107).

Vaattovaara $(2015,41)$ muistuttaa siitä, ettei toimijuus toteudu aina näkyvinä valintoina, vaan se voi olla esimerkiksi kulttuurisesti rutiininomaista toimintaa tai normeissa pitäytymistä. Tietynlaiseen toimijuuteen on myös mahdollista ajautua taloudellisten, sosiaalisten tai kulttuuristen lähtökohtien tai olosuhteiden vaikuttamana (Vaattovaara 2015, 78). Honkasalo $(2013,42)$ on kuvaillut "pieneksi toimijuudeksi" sellaista näennäisesti paikallaan pysyvää toimintaa, jonka muotoja ovat odottaminen, sietäminen ja jääminen. Näin ollen toimijuus kytkeytyy aktiivisen toiminnan lisäksi myös olemiseen (Åkerblad 2014, 44), johon kuitenkin voidaan nähdä olevan liitoksissa sekä yksilön valinta että valinnan mahdollisuudet.

Toimijuuteen vaikuttavat muun muassa ikä, sukupuoli ja monenlaiset kulttuuriset tekijät, jotka voidaan nähdä toimijuutta koordinoivina, muokkaavina ja rakentavina elementteinä. Myös näiden elementtien välisellä dynamiikalla on vaikutusta toimijuuden muodostumiseen. Esimerkiksi henkilön ikään liittyy erilaisia sosiaalisia odotuksia, oikeuksia ja velvollisuuksia, jotka ovat puolestaan kytköksissä toimijuuteen ja sen ilmenemiseen. (Jyrkämä 2008, 193-194.) Herkkyyden käsitteen teoreettiseen tarkasteluun perustuen voidaan todeta myös herkkyyden olevan yksi 
niistä tekijöistä, jotka liittyvät yksilön toimijuuden kokonaisuuteen ja sen rakentumiseen. Eri ihmisten kohdalla yhdistyy yksilöllisinä kokonaisuuksina monia erilaisia taustatekijöitä sekä yhteiskunnallisesti määrittyneitä asemia ja kategorioita, kuten esimerkiksi ikä ja sukupuoli, joista yhdessä rakentuu kunkin ihmisen yksilöllinen toiminnan ja olemisen kehys (ks. lisää risteävistä eroista esim. Nivala \& Ryynänen 2019, 178).

\section{Toiminnan mahdollisuudet ja hyvä elämä}

Edellä kuvaamamme yksilöllinen olemisen kehys ja siinä tapahtuva toimijuus ovat vahvasti tilannesidonnaisia. Erilaisten elämäntilanteiden rakentumisen kautta näkökulmaa voidaan edelleen laajentaa hyvinvoinnin teemoihin, elämänlaatuun ja hyvään elämään (Jyrkämä 2008, 192-193). Salosen ja Oksasen $(2011,7)$ mukaan hyvinvointi ja elämässä pärjääminen edellyttävät, että ihmisellä on mahdollisuuksia toimia tavalla, jonka kokee itselleen mielekkääksi. Yksilöllä tulee olla mahdollisuus valita itse oman toimijuutensa tavat ja muodot, kunhan toiminta ei vahingoita muita. Sosiaalipedagogisesta näkökulmasta keskeistä on toimijuuden omaehtoisuus eikä niinkään se, miten aktiivista toimijuus on luonteeltaan. Toimijuuden edellytyksenä ovat toiminnan mahdollisuudet sekä niiden edistäminen. Toiminnan mahdollisuuksiin sisältyy olennaisena osana vapaus: yksilön valinta siitä, millaista hänen oma toimijuutensa on. (Nivala \& Ryynänen 2019, 104-105.) Yksilön valta käyttää omaa valinnanvapauttaan ilmentää toimijuutta eri tavoin kuin pakon edessä tapahtuva toimijuus (Vaattovaara 2015, 77). Pakko, alistaminen ja vaihtoehdottomuus muokkaavat toimijuutta kapea-alaisemmaksi (Ronkainen 2008, 388).

Tämän artikkelin näkökulma toimijuudesta ja toiminnan mahdollisuuksista kiinnittyy vahvasti Nussbaumin ja Senin toimintamahdollisuusteoriaan, jonka mukaan toiminnan mahdollisuuksia tulisi edistää siten, että jokaisella olisi mahdollisuus toimia omien tavoitteidensa mukaisesti ja elää omannäköistään, inhimillistä ja arvokasta elämää (Nussbaum 2011; Sen 1993; ks. Björklund \& Sarlio-Siintola 2010, 37-43; Mäntyneva \& Isola 2019, 248; Nivala \& Ryynänen 2019, 100-105). Teoria sisältää jäsennyksen kymmenestä inhimillisestä toimintamahdollisuudesta. Toimintamahdollisuudet lähtevät liikkeelle 1) mahdollisuudesta elää inhimillinen ja elämisen arvoinen elämä, jossa on 2) mahdollisuus hyvään terveyteen sekä 3) ruumiilliseen koskemattomuuteen. Tähän kuuluu myös 4) mahdollisuus käyttää aisteja, mielikuvitusta ja ajattelua, sekä 5) kokea ja osoittaa tunteita. Inhimillisten toimintamahdollisuuksien mukaisesti täytyy ol- 
la 6) mahdollisuus muodostaa oma käsityksensä hyvästä elämästä ja tehdä siihen kuuluvia päätelmiä. Lisäksi tarvitaan 7) yhteenkuuluvuutta toisten ihmisten kanssa, kuten myös 8) yhteyttä ympäröivään luontoon, eläimiin ja kasveihin. Täytyy olla 9) mahdollisuus leikkiin ja iloon. Inhimillisten toimintamahdollisuuksien jäsennys päättyy 10) mahdollisuuteen oman ympäristön hallintaan, johon kuuluu niin poliittinen kuin materiaalinen päätöksenteko. (Nussbaum 2011, 33-34.) Toimintamahdollisuuksien jäsennyksen pohjalta voidaan hahmotella hyvän elämän edellytysten rakentumista vapauksien ja valintojen näkökulmasta. Lisäksi sen avulla voidaan pureutua kysymykseen siitä, miten ihmisten toiminnallisten valmiuksien kehittymistä ja käyttöä voitaisiin tukea. (Nivala \& Ryynänen 2019, 101102.)

Toimijuus on siis keskeinen osa toimintamahdollisuusteoriaa: toimijuuden ja toimintamahdollisuuksien välillä voidaan nähdä tiivis käsitteellinen yhteys (Jyrkämä 2008, 191, 200). Kun halutaan edistää toimijuutta, on olennaista tukea toiminnan mahdollisuuksia (Nivala \& Ryynänen 2019, 104). Jäsennys inhimillisistä toimintamahdollisuuksista on sovellettavissa erilaisiin konteksteihin ja toimintaympäristöihin (ks. Pirhonen 2013). Vaikka toimintamahdollisuudet vaikuttavat pääpiirteissään yleisinhimillisiltä, on oltava varovainen kategorisissa tulkinnoissa ja huomioitava yksilöllinen konteksti- ja tilannesidonnainen näkökulma. Toiminnan mahdollisuudet rakentuvat yksilöllisessä olemisen kehyksessä eli siinä ympäristössä, jossa ihminen elää. Ne voivat painottua hyvän elämän näkökulmasta yksilöllisesti eri tavoin: jonkin yksittäisen toimintamahdollisuuden painottuminen saattaa olla jollekin ihmiselle oman elämän kannalta erityisen tärkeäksi koettu avain toimijuuteen ja hyvään elämään, mitä se ei kuitenkaan välttämättä kaikkien kohdalla ole.

Herkkyyden moninaisuus tuo mukanaan vielä lisää variaatioita toimintamahdollisuuksien yksilölliseen painottumiseen. Esimerkiksi Manninen $(1999,174-175$, ks. myös 99-101) on kuvannut lapsenkaltaisuutta tutkimiensa väri-ihmisten ominaisuutena. Hän on todennut leikkisyyden olevan kiinteästi yhteydessä yliherkkien väri-ihmisten hyvinvointiin: heillä on oltava mahdollisuus leikkiin ja iloon, ja heissä on sisäänrakennettu perustavanlaatuinen tarve oman ilonsa ilmaisemiselle (Honkavaara 1958c, 46, 49). Mahdollisuus leikkiin ja iloon on yksi toimintamahdollisuusteoriaan sisältyvistä kymmenestä inhimillisestä toimintamahdollisuudesta. Kyseessä on keskeinen tarve, jolla on suora vaikutus yksilön hyvinvointiin. Vaikka joidenkin toimintamahdollisuuksien (kuten leik- 
kisyyden) painoarvo näyttäisi erityisen merkitykselliseltä juuri herkille ihmisille, on tärkeää tunnistaa herkkyyden moninaisuus, antaa tilaa yksilöllisyydelle ja välttää stereotyyppisiä kuvauksia.

Toimintamahdollisuuksien teoreettisesta lähestymistavasta on tunnistettavissa yhtäläisyyksiä sosiaalipedagogisen ajattelun ja lähestymistavan kanssa, joten se sopii sosiaalipedagogisen tutkimuksen viitekehykseksi (Nivala \& Ryynänen 2019, 100, 103). Se, miten hyvän elämän edellytykset rakentuvat yksilön arjessa, voi paljastaa näköaloja myös institutionaalisiin ja yhteiskunnallisiin rakenteisiin: minkälaiset ovat inhimillisen toiminnan edellytykset ja mahdollisuudet näissä rakenteissa (Jokinen 2005, 12).

\section{Pohdinta}

Olemme tässä artikkelissa kuvanneet herkkyyttä ympäristölle tutkimusten ja tutkimustraditioiden valossa. Lisäksi olemme käsitteellistäneet olemisen kehykseksi kutsumaamme kokonaisuutta, jossa herkkyydeltään erilaiset ihmiset elävät. Tässä artikkelissa kuvaamamme olemisen kehys voidaan ymmärtää monitasoisena ja monitahoisena käsitteenä, joka kietoo yhteen sekä yksilön toimijuuden että yksilöiden väliset herkkyyserot. Kun todellisuutta tarkastellaan käsitteen avaaman ymmärryksen avulla, päästään kiinni siihen kokemusmaailmaan, jossa herkkyydeltään erilaiset ihmiset elävät. Suomalaisessa tutkimuskirjallisuudessa herkkyys ympäristölle on toistaiseksi lähes tuntematon käsite. Tämä voi johtua siitä, että kotimaista tutkimusta aiheesta on toistaiseksi erittäin vähän, ja kansainvälisessä tutkimuskirjallisuudessa ilmiön tutkimus on levittäytyneenä erilaisten käsitteiden alle.

Käsityksemme mukaan herkkyyden ymmärtämisessä tarvitaan ymmärrystä ihmisten sisäisestä kokemusmaailmasta. Tutkimuksenteon kannalta yksilöllisen kokemusmaailman tavoittaminen on subjektiivisuudessaan haasteellinen alue. Tutkija ei todennäköisesti koskaan tavoita kaikille herkillekään ihmisille yhteistä kokemusta vaan yksilöllisiä, merkityksellisiä kokemuksia ja kokemisen tapoja. Näistä yksilöllisistä kokemuksista saattaa hahmottua samankaltaisuuksia. Esimerkiksi Manninen (1999) on todennut herkkien ihmisten kokevan keskimäärin enemmän vierauden tunnetta verrattuna vähemmän herkkiin. Tässä artikkelissa olemme keskittyneet perustaltaan neurobiologisiin herkkyyseroihin, jotka kytkeytyvät ihmisten luontaiseen temperamenttiin. Tarkastelun ulkopuolelle olemme jättäneet esimerkiksi neurologiset häiriöt. Ihmisen yksilöllisessä persoonallisuudessa monet ominaisuudet ja mahdolliset häiriötkin voivat 
linkittyä toisiinsa ja vaikuttaa myös yksilöllisen kokemusmaailman muotoutumiseen.

Ilmiön käsitteellistämiseen liittyvä kysymys on, tulisiko suomenkielisessä tieteellisessä keskustelussa käyttää lainkaan erityisherkkyyden käsitettä, joka on Elaine Aronin tietokirjasuomennosten käsite. Suomenkielisen termin "erityis"-etuliite poikkeaa englanninkielisestä ilmaisusta. Esimerkiksi Lionettin ym. (2018) käyttämä jaottelu low-, medium- ja high-sensitive viittaa suomenkielistä termiä neutraalimmin siihen, että kyseessä on jatkumo, jolle yksilöt sijoittuvat eri kohtiin (Honkavaara 1964, 169; Lionetti ym. 2018; Manninen 1999, 13; ks. myös Pluess ym. 2018, 65). Tässä artikkelissa olemme päätyneet välttämään Aronin tietokirjakäännöksistä suomen kieleen tullutta erityisherkkyyden käsitettä. Jatkossakin on suositeltavaa suhtautua käsitteistöön kriittisesti. Olisi toivottavaa, että suomalaisessa tieteellisessä keskustelussa olisi käytössä suomenkielisiä käsitteitä, vaikka tutkimuskirjallisuus on pääosin englanninkielistä ja käsitteistö osittain tieteenalastakin riippuvaa. Käytännön syistä voi olla tarpeen puhua erityisherkistä ihmisistä esimerkiksi tutkimuskutsussa, koska nimenomaan erityisherkkyyden käsite on monille tuttu. Haastattelututkimuksissa joudutaan tällöin tasapainoilemaan teoreettiseen viitekehykseen liittyvän käsitteistön ja tutkimuksen osallistujien tuottaman aineiston käsitteistön välillä (ks. Hyvärinen 2017, 24-25, 38). Honkavaara (1958c, 48) mainitsee, että erityisen herkillä ihmisillä on sisäinen tarve tulla ymmärretyiksi ja hyväksytyiksi. Tutkimuksen eettisyyden näkökulmasta tämä tarve tulee ottaa huomioon silloin, kun ollaan vuorovaikutuksessa erityisen herkkien ihmisten kanssa.

Tietous yksilöllisistä herkkyyseroista sekä herkkyydestä ympäristölle on näkemyksemme mukaan sovellettavissa laajasti erilaisissa hyvinvointiin ja sen tukemiseen ja lisäämiseen liittyvissä yhteyksissä, muun muassa erilaisissa kasvatuskonteksteissa. Sen suuntaamiseen on monia erilaisia mahdollisuuksia: esimerkiksi Ollila ja Kujala (2020) ovat yhdistäneet erityisherkkyyden tarkastelun työhyvinvointiin ja johtamiseen. Tarkempia johtopäätöksiä varten tarvitaan kuitenkin empiirisiin aineistoihin pohjautuvia tutkimuksia. 


\section{LÄHTEET}

Acevedo, B. P., Aron, E., Aron, A., Sangster, M.-D., Collins, N. \& Brown, L. L. 2014. The highly sensitive brain: an fMRI study of sensory processing sensitivity and response to others' emotions. Brain and Behavior 4 (4), 580-594. DOI: https://doi.org/10.1002/ brb3.242.

Aron, E. N. 2013. Erityisherkkä ihminen. Alkuperäisteos (1999) The Highly Sensitive Person: How to Thrive When the World Overwhelms You, suomentanut Sini Linteri. Helsinki: Nemo.

Aron, E. \& Aron, A. 1997. Sensory-Processing Sensitivity and Its Relation to Introversion and Emotionality. Journal of Personality and Social Psychology 73 (2), 345-368. DOI: https://doi.org/10.1037/0022-3514.73.2.345.

Aron, E. \& Aron, A. 2018. Tips for SPS research. Saatavissa https://hsperson.com/wpcontent/uploads/2018/08/Tips_for_SPS_Research_Revised_July24_2018.pdf (haettu 08.03.2021).

Aron, E., Aron, A. \& Davies, K. 2005. Adult Shyness: The Interaction of Temperamental Sensitivity and an Adverse Childhood Environment. Personality \& Social Psychology Bulletin 31 (2), 181-197. DOI: https://doi.org/10.1177/0146167204271419.

Aron, E., Aron, A. \& Jagiellowicz, J. 2012. Sensory Processing Sensitivity: A Review in the Light of the Evolution of Biological Responsivity. Personality and Social Psychology Review 16 (3), 262-282. DOI: https://doi.org/10.1177/1088868311434213.

Assary, E., Zavos, H. M. S., Krapohl, E., Keers, R. \& Pluess, M. 2021. Genetic architecture of Environmental Sensitivity reflects multiple heritable components: a twin study with adolescents. Molecular Psychiatry 26, 4896-4904. DOI: https://doi.org/10.1038/ s41380-020-0783-8.

Belsky, J. 1997. Variation in Susceptibility to Environmental Influence: An Evolutionary Argument. Psychological Inquiry 8 (3), 182-186. DOI: https://doi.org/10.1207/ s15327965pli0803_3.

Belsky, J., Bakermans-Kranenburg, M. J. \& van IJzendoorn, M. H. 2007. For Better and for Worse: Differential Susceptibility to Environmental Influences. Current Directions in Psychological Science: a Journal of the American Psychological Society 16 (6), 300304. DOI: https://doi.org/10.1111/j.1467-8721.2007.00525.x.

Belsky, J. \& Pluess, M. 2009. Beyond Diathesis Stress: Differential Susceptibility to Environmental Influences. Psychological Bulletin 135 (6), 885-908. DOI: https://doi. org/10.1037/a0017376.

Björklund, R. \& Sarlio-Siintola, S. 2010. Inhimilliset toimintavalmiudet suomalaisessa hyvinvointipolitiikassa. Teoksessa H. Hiilamo \& J. Saari (toim.) Hyvinvoinnin uusi politiikka - johdatus sosiaalisiin mahdollisuuksiin. Tampere: Diakoniaammattikorkeakoulu, 37-70.

Boyce, W. T. \& Ellis, B. J. 2005. Biological sensitivity to context: I. An evolutionarydevelopmental theory of the origins and functions of stress reactivity. Development and Psychopatology 17 (2), 271-301. DOI: https://doi.org/10.1017/S0954579405050145. 
Bronfenbrenner, U. 1977. Toward an Experimental Ecology of Human Development. The American Psychologist 32 (7), 513-531. DOI: https://doi.org/10.1037/0003066X.32.7.513.

Chess, S. \& Thomas, A. 1991. Temperament and the Concept of Goodness of Fit. Teoksessa J. Strelau \& A. Angleitner (eds.) Explorations in Temperament. Perspectives on Individual Differences. Boston: Springer. DOI: https://doi.org/10.1007/978-14899-0643-4_2.

de Villiers, B., Lionetti, F. \& Pluess, M. 2018. Vantage sensitivity: a framework for individual differences in response to psychological intervention. Social Psychiatry and Psychiatric Epidemiology 53, 545-554. DOI: https://doi.org/10.1007/s00127017-1471-0.

Ellis, B., Boyce, W., Belsky, J., Bakermans-Kranenburg, M. J. \& van IJzendoorn, M. H. 2011. Differential susceptibility to the environment: An evolutionaryneurodevelopmental theory. Development and Psychopathology 23 (1), 7-28. DOI: https://doi.org/10.1017/S0954579410000611.

Greven, C., Lionetti, F., Booth, C., Aron, E., Fox, E., Schendan, H., Pluess, M., Bruining, H., Acevedo, B., Bijttebier, P. \& Homberg, J. 2019. Sensory Processing Sensitivity in the context of Environmental Sensitivity: A critical review and development of research agenda. Neuroscience and Biobehavioral Reviews 98, 287-305. DOI: https:// doi.org/10.1016/j.neubiorev.2019.01.009.

Hipson, W. \& Séguin, D. 2020. Goodness of Fit Model. In V. Zeigler-Hill \& T. K. Shackelford (eds.) Encyclopedia of Personality and Individual Differences. Cham: Springer International Publishing, 1823-1825. DOI: https://doi.org/10.1007/978-3319-24612-3_757.

Honkasalo, M.-L. 2013. Katveessa - pieni toimijuus kriittisenä avauksena toiminnan teoriaan. Tiede \& edistys 38 (1), 42-61. DOI: https://doi.org/10.51809/te.105092.

Honkavaara, S. 1958a. A Critical Reevaluation of the Color and Form Reaction, and Disproving of the Hypotheses Connected with it. The Journal of Psychology 45 (1), 25-36.

Honkavaara, S. 1958b. Relation of Interpersonal Preference and Emotional Attitude of the Subject. The Journal of Psychology 46 (1), 25-31.

Honkavaara, S. 1958c. The Color and Form Reaction as a Basis for Differential Psychotherapeutic Approach. The Journal of Psychology 46 (1), 39-51.

Honkavaara, S. 1964. The Color and Form Personality and the Recognition of the Type Through the Physiognomic Structure of the Face. Acta Psychologica 22, 169-190.

Hyvärinen, M. 2017. Haastattelun maailma. Teoksessa M. Hyvärinen, P. Nikander \& J. Ruusuvuori (toim.) Tutkimushaastattelun käsikirja. Tampere: Vastapaino, 11-45.

Iimura, S. \& Kibe, C. 2020. Highly Sensitive Adolescent in Positive School Transitions: Evidence for Vantage Sensitivity in Japanese High-Schoolers. Developmental Psychology 56 (8), 1565-1581. DOI: https://doi.org/10.1037/dev0000991.

Jagiellowicz, J., Aron, A. \& Aron. E. 2016. Relationship Between the Temperament Trait of Sensory Processing Sensitivity and Emotional Reactivity. Social Behavior and Personality 44 (2), 185-199. DOI: https://doi.org/10.2224/sbp.2016.44.2.185. 
Jagiellowicz, J., Xu, X., Aron, A., Aron, E., Cao, G., Feng, T. \& Weng, X. 2011. The trait of sensory processing sensitivity and neural responses to changes in visual scenes. Social Cognitive and Affective Neuroscience 6 (1), 38-47. DOI: https://doi:10.1093/ scan/nsq001.

Jokinen, E. 2005. Aikuisten arki. Helsinki: Gaudeamus.

Jyrkämä, J. 2008. Toimijuus, ikääntyminen ja arkielämä - hahmottelua teoreettismetodologiseksi viitekehykseksi. Gerontologia 22 (4), 190-203.

Keltikangas-Järvinen, L. 2009. Temperamentti - persoonallisuuden biologinen selkäranka. Teoksessa R.-L. Metsäpelto \& T. Feldt (toim.) Meitä on moneksi: Persoonallisuuden psykologiset perusteet. Jyväskylä: PS-Kustannus, 49-69.

Keltikangas-Järvinen, L. 2016. ”Hyvät tyypit”: temperamentti ja työelämä. Helsinki: WSOY.

Laulainen, S. 2010. "Jos mittää et anna niin mittää et saa": strateginen toimijuus ja organisaatiokansalaisuus vanhustyössä. Väitöskirja. Kuopio: Itä-Suomen yliopisto.

Lionetti, F., Aron, A., Aron, E., Burns, G., Jagiellowicz, J. \& Pluess, M. 2018. Dandelions, tulips and orchids: evidence for the existence of low-sensitive, medium-sensitive and high-sensitive individuals. Translational Psychiatry 8 (1), 24-11. DOI: https://doi. org/10.1038/s41398-017-0090-6.

Lionetti, F., Pastore, M., Moscardino, U., Nocentini, A., Pluess, K. \& Pluess, M. 2019. Sensory Processing Sensitivity and its association with personality traits and affect: A meta-analysis. Journal of Research in Personality 81, 138-152. DOI: https://doi. org/10.1016/j.jrp.2019.05.013.

Manninen, S.-S. 1999. Outolintu, erilainen: Tutkimusraportti yliherkästä väri-ihmisestä muotojen yhteiskunnassa. Jyväskylä: Atena.

Metsäpelto, R.-L. \& Rantanen, J. 2009. Persoonallisuuden piirteet ihmisen samanlaisuuden ja erilaisuuden kuvaajina. Teoksessa R.-L. Metsäpelto \& T. Feldt (toim.) Meitä on moneksi: Persoonallisuuden psykologiset perusteet. Jyväskylä: PS-Kustannus, 71-90.

Mäntyneva, P. \& Isola, A.-M. 2019. Toimintamahdollisuuksien avaruus ja toimijuuden suunnat kuntouttavassa työtoiminnassa. Janus 27 (3), 246-263. DOI: https://doi. org/10.30668/janus.70286.

Nivala, E. \& Ryynänen, S. 2019. Sosiaalipedagogiikka: kohti inhimillisempää yhteiskuntaa. Helsinki: Gaudeamus.

Nocentini, A., Menesini, E. \& Pluess, M. 2018. The Personality Trait of Environmental Sensitivity Predicts Children's Positive Response to School-Based Antibullying Intervention. Clinical Psychological Science 6 (6), 848-859. DOI: https://doi. org/10.1177/2167702618782194.

Nolvi, S., Tuulari, J. J., Lavonius, T., Scheinin, N. M., Lehtola, S. J., Lavonius, M., Merisaari, H., Saunavaara, J., Korja, R., Kataja, E.-L., Pelto, J., Parkkola, R., Karlsson, R. \& Karlsson, H. 2020. Newborn white matter microstructure moderates the association between maternal postpartum depressive symptoms and infant negative reactivity. Social Cognitive and Affective Neuroscience 15 (6), 649-660. DOI: https:// doi.org/10.1093/scan/nsaa081.

Nussbaum, M. 2011. Creating capabilities: the human development approach. Harvard: Harvard University Press. 
Ollila, S. \& Kujala, A. 2020. Moninaisuus työelämässä ja johtamisessa - erityisherkät persoonat työssä. Hallinnon tutkimus 39 (2), 90-102. DOI: https://doi.org/10.37450/ ht.98083.

Pirhonen, J. 2013. Toimintamahdollisuudet vanhojen ihmisten pitkäaikaishoidossa. Gerontologia 27 (2), 58-72.

Pluess, M. 2015. Individual Differences in Environmental Sensitivity. Child Development Perspectives 9 (3), 138-143. DOI: https://doi.org/10.1111/cdep.12120.

Pluess, M., Assary, E., Lionetti, F., Lester, K. J., Krapohl, E., Aron, E. N. \& Aron, A. 2018. Environmental Sensitivity in Children: Development of the Highly Sensitive Child Scale and Identification of Sensitivity Groups. Developmental Psychology 54 (1), 51-70. DOI: https://doi.org/10.1037/dev0000406.

Pluess, M. \& Belsky, J. 2013. Vantage Sensitivity: Individual Differences in Response to Positive Experiences. Psychological Bulletin 139 (4), 901-916. DOI: https://doi. org/10.1037/a0030196.

Pluess, M. \& Boniwell, I. 2015. Sensory-Processing Sensitivity predicts treatment response to a school-based depression prevention program: Evidence of Vantage Sensitivity. Personality and Individual Differences 82, 40-45. DOI: https://doi.org/10.1016/j. paid.2015.03.011.

Ronkainen, S. 2008. Kenen ongelma väkivalta on? Suomalainen hyvinvointivaltio ja väkivallan toimijuus. Yhteiskuntapolitiikka 73 (4), 388-401.

Salonen, M. \& Oksanen, A. 2011. Yksilölliset ja yhteiskunnalliset ansat. Teoksessa A. Oksanen \& M. Salonen (toim.) Toiminnallisia loukkuja: hyvinvointi ja eriarvoisuus yhteiskunnassa. Tampere: Tampere University Press, 7-16.

Sen, A. 1993. Capability and Wellbeing. Teoksessa M. Nussbaum \& A. Sen. The Quality of Life. Oxford: Oxford University Press, 30-54.

Slagt, M., Dubas, J. S., Deković, M. \& van Aken, M. A. G. 2016. Differences in Sensitivity to Parenting Depending on Child Temperament: A Meta-Analysis. Psychological Bulletin 142 (10), 1068-1110. DOI: https://doi.org/10.1037/bul0000061.

Smolewska, K. A., McCabe, S. B. \& Woody, E. Z. 2006. A Psychometric evaluation of the Highly Sensitive Person Scale: The components of sensory-processing sensitivity and their relation to the BIS/BAS and "Big Five". Personality and Individual Differences 40 (6), 1269-1279. DOI: https://doi.org/10.1016/j.paid.2005.09.022.

Sobocko, K. \& Zelenski, J. 2015. Trait sensory-processing sensitivity and subjective wellbeing: Distinctive associations for different aspects of sensitivity. Personality and Individual Differences 83, 44-49. DOI: https://doi.org/10.1016/j.paid.2015.03.045.

Vaattovaara, V. 2015. Elämänkulku ja toimijuus: Lapin maaseudun nuorista aikuisiksi 1990-2011. Väitöskirja. Rovaniemi: Lapin yliopisto.

Vander Elst, T., Sercu, M., Van den Broeck, A., Van Hoof, E., Baillien, E. \& Godderis, L. 2019. Who is more susceptible to job stressors and resources? Sensory-processing sensitivity as a personal resource and vulnerability factor. PLoS ONE 14 (11), e0225103. DOI: https://doi.org/10.1371/journal.pone.0225103. 
Värri, V.-M. 2002. Kasvatus ja "ajan henki" - tulkintoja psykokapitalismin armottomuudesta. Aikuiskasvatus 22 (2), 92-104. DOI: https://doi.org/10.33336/ aik.93405.

Wolf, M. G., van Doorn, S. \& Weissing, F. J. 2008. Evolutionary emergence of responsive and unresponsive personalities. Proceedings of the National Academy of Sciences PNAS 105 (41), 15825-15830. DOI: https://doi.org/10.1073/pnas.0805473105.

Åkerblad, L. 2014. Epävarmuuden tuolla puolen: muuttuvat työmarkkinat ja prekaari toimijuus. Väitöskirja. Joensuu: University of Eastern Finland. 